\title{
Great expectations but little evidence: policing money laundering
}

\author{
Antoinette Verhage \\ Ghent University, Ghent, Belgium
}

\begin{abstract}
Purpose - The purpose of this paper is to map anti-money laundering policy and its impact on money laundering. The AML system is discussed from the perspective of the compliance officer, who is responsible for translating AML law into practice in Belgian banks.

Design/methodology/approach - Literature review, based largely on a PhD study (2009) that involved a survey and interviews. Additionally, 12 compliance officers were interviewed in 2015.

Findings - The global AML system impacts significantly on issues of privacy and due process but has not yet been evaluated. The system's preventive effect is difficult to measure because of a lack of (cross-border) information. The way in which Risks are currently managed in diverse ways.

Research limitations/implications - Results from the first study in 2009 (based on interviews in 20072008) were potentially outdated. This recent update (2015) confirms that compliance officers are still dealing with the same issues.

Practical implications - The study clarifies the ways in which compliance and AML is dealt with and mapped, providing insights into an often closed setting.

Social implications - The battle against money laundering is very costly and intrusive, making the need for stringent evaluation more pressing.

Originality/value - The study is both original and valuable because compliance officers have rarely been the subject of research. The study discloses useful information about their role.

Keywords AML, Policing, Compliance, Money laundering, Financial crime, Criminology

Paper type Research paper
\end{abstract}

\section{Introduction}

In most European countries, including Belgium, money laundering was inserted in the penal code more than 25 years ago. Since then, an impressive apparatus of anti-money laundering (AML) and compliance initiatives has been established, based in large degree on European regulations. Through their reporting function, financial institutions were positioned as important gatekeepers to this AML system. This paper begins by positioning money laundering within the context of financial crime before exploring the problems encountered in pursuing insights into the phenomenon. The AML system will be discussed, focusing on the perspective of the compliance officers who are responsible for translating AML law into practice in Belgian banks. This perspective is adopted in an attempt to show that the policing of money laundering is less straightforward than it may seem. In combination with the recent FATF evaluation (2015), a small-scale study of compliance officers (2015) places the results in contemporary perspective and addresses the recent evolution of the compliance sector, as well as touching upon issues such as uniformity, level playing field and, ultimately, effectiveness.

(c) Antoinette Verhage. Published by Emerald Publishing Limited. This article is published under the Creative Commons Attribution (CC BY 4.0) licence. Anyone may reproduce, distribute, translate and create derivative works of this article (for both commercial \& non-commercial purposes), subject to full attribution to the original publication and authors. The full terms of this licence may be seen at $\mathrm{http} / / /$ creativecommons.org/licences/by/4.0/legalcode

This paper is based largely on a study that was funded by FWO-Vlaanderen.

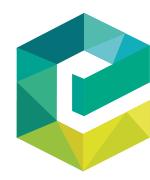

Received 27 June 2016 Accepted 27 June 2016

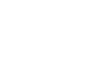


IJSSP

$37,7 / 8$

478

\section{Money laundering as financial crime}

Financial crime is a broad concept encompassing different types of crime (Gottschalk, 2010). Authors continue to struggle with questions of definition, such as how white collar crime relates to financial crime (Piquero and Clipper, 2014). While "fraud" is often used as an overarching term (De Bie and Verhage, 2010), some authors adopt a perpetrator-centered definition of white collar crime as including both corporate and employee crime (Geis, 1993). However, financial crime may not always be about the perpetrator so much as about the method (concealment, misleading) and the goal (financial, profit-making). To date, no comprehensive or unequivocal definition has been developed (Gottschalk, 2010).

In Belgium, financial-economic crime is not a hot topic, either in criminology or in crimefighting practice, despite social developments that work in favor of financial crime. The increased possibilities of online payments, online banking and digital money have also boosted the opportunities for committing financial crime (Croall, 2001; Moore, 2013), suggesting that the phenomenon therefore deserves greater attention. It is also known that victims of financial crime can perceive it as very intrusive, and its impact can be felt on a large scale (Gottschalk, 2010). The last ten years have seen a significant number of such crimes, in Belgium and elsewhere, which have been the subject of extensive media coverage[1]. The financial crisis has clearly demonstrated the importance of a healthy financial system, especially in a society that emphasizes and prioritizes the influence of corporations and the corporate world more generally (Braithwaite, 2000).

Empirical criminological research into financial crime remains relatively marginal. Slapper and Tombs (1999) referred to this phenomenon over 15 years ago in relation to corporate crime as the "self-perpetuating cycle of omission and ignorance." In failing to recognize the increased opportunities for financial crime, or to take a more active approach to the study of financial crime, criminology seems to have missed the boat with regard to what remains a niche in criminological research. This conclusion was reached ten years ago in a review of criminological education and publications (Lynch et al., 2004) but remains the case today. A more recent review of publications in criminology[2] shows that little has changed; white collar crime is still largely overlooked by criminology, with only 6.3 percent of all articles addressing this area (McGurrin et al, 2013), and the first Handbook of White-Collar and Corporate Crime in Europe was published only very recently (van Erp, Huisman and Vande Walle, 2015). This lack of academic and policy attention is also reflected in the limited statistics on financial crime at both international (McGurrin et al, 2013) and national level. This leads to a vicious circle: poor access and availability of data presents hurdles and difficulties for researchers who try to study the phenomenon, leading in turn to a loss of priority on the research agenda.

\section{Limited visibility}

The following paragraphs will review existing insights into financial crime (specifically, money laundering) to illustrate how limited this information actually is. Turning first to the numerous sources of data on money laundering, these are characterized by differing backgrounds, contexts and approaches to measurement.

Among these[3], traditional sources (to which most criminologists would turn) largely comprise information from the judicial chain, such as police and other statistics relating to prosecution and convictions. A second category, research sources, consist of self-report studies and victim surveys (e.g. ESS or the Survey on White Collar Crime). Third, policy-related sources - reports by the authorities - can provide additional information for research purposes (e.g. studies by the European Commission such as that preceding the 4th AML Directive). A fourth source is information from supervisory authorities such as the FIU or inspection agencies, who publish annual reports on cases reported to them. Finally, private sector reports from commercial organizations involved in the investigation of 
financial crime (e.g. Big 4 accounting firms, insurance companies and complaint services) Policing money can be a valuable source of information.

Each of these sources has its own measuring problems. For instance, traditional sources are deficient in that the dark figure of financial crime is usually relatively high, resulting in a very limited view (Shoham et al., 2010). This implies that many infractions will never be disclosed. Victim surveys, such as the ICVS (International Crime Business Survey (Frate, 2004)) and the Dutch "Monitor Criminaliteit Bedrijfsleven," do give us some insights, even though they are limited, as these relate to victimization by corporations (WODC, 2011)[4]. Self-reports also reveal a limited picture, although there is some research that attempts to map the causes of financial crime (Blickle et al, 2006; Collins and Schmidt, 1993; Kabki, 2014). Other types of academic study, such as file analyses, are very rare; these can be valuable but shed light only on what is detected by the judicial chain or by inspections.

Policy-related sources, such as reports by the European Commission or Eurostat[5], seek to provide an overarching picture of crime or crime phenomena by questioning member states about specific types of crime. Here, researchers are largely dependent on the quality of data in each member state. While noting the limitations of these reports, they can nevertheless provide insights into relative incidence across countries, as in the recent EU Anti-Corruption Report (European Commission, 2014).

Supervisory authorities can add important value to research, as their databases provide an overview of types of financial crime that may never reach the judicial chain. As one important example, the FIU reports annually (at least in Belgium) on their files. These annual reports (see www.ctif-cfi.be) provide important insights into detected cases of financial crime. Other such examples include annual reports by inspection agencies.

Private information can provide additional perspectives on another piece of the puzzle: the extent to which companies encounter certain types of financial crime. This category includes reports by private organizations such as KPMG, Deloitte or Price Waterhouse Coopers, who publish regularly on trends relating to types of financial crime or to enforcement issues such as compliance (Verhage, 2008; Deloitte, 2011; KPMG, 2007; Price Waterhouse Coopers, 2005).

In short, there are difficulties in assessing the epidemiology of financial crime, and of money laundering in particular; information is scattered, fragmented, or missing. The authors of one European study seeking to make an impact assessment of money laundering could only conclude that the currently available information does not even enable a baseline measurement (European Commission, 2013). In addition, those sources that are available should be used with care, as some lack detail, referring to "white collar crime" in general or failing to clarify what is included in the recorded cases.

\section{Studying AML measures in Belgium: the AML complex}

\subsection{Background to the fight against money laundering}

Money laundering has been considered a crime since the late 1980s, and has been an issue for European member states since that time. Across Europe, the fight against money laundering typically involves a dual approach, combining preventive and repressive measures (Reuter and Truman, 2005) and including both public and private partners. From the 1990s onward, three European Directives have governed how money laundering is tackled[6]. These Directives have all been implemented in Belgian law, with several consequences. First, the Directives asserted that a preventive approach was needed to combat money laundering; the repressive approach, characterized by criminal investigations centered on "following the money," was not considered sufficient. Second, this preventive approach is built on the detection and reporting of suspicious transactions. The fourth European Directive, which came into force on 25 June 2015, reinforces the preventive approach with an intensified risk-based approach that involves risk assessment 
IJSSP

$37,7 / 8$

480

and client identification, striving for a level playing field and imposing the development of a central register of beneficial ownership[7].

Today, multiple international actors are united in the battle against money laundering by preventing, detecting, investigating and reporting potential cases. It is precisely this allinclusive approach that characterizes AML, uniting actors in what has been called an AML complex (Verhage, 2009, 2011), comprising diverse services, individuals and organizations. The goal of this complex (Bisschop and Verhage, 2012), is to deploy national and international regulation and legislation to fight the laundering of money. In Belgium, this endeavor includes both public and private organizations, cooperating to prevent and investigate the laundering of crime-related money; actors include the (federal) police and public prosecutors, the FIU, the Central Office for Seizure and Confiscation and supervisory authorities for the financial sector.

Beyond these public organizations at national level, private organizations constitute an essential part of the AML complex, as they are obliged to report suspicious transactions to the FIU. This reporting system makes the fight against money laundering unique as a coalition of public and private partners involved in all-inclusive surveillance. Organizations that are expected to cooperate in this system are listed in the Belgian AML legislation; these include both financial organizations such as banks, insurance companies and investment companies, along with non-financial groups such as lawyers, notaries, security companies, casinos and dealers in high-value goods. In 2011, more than 58,000 individuals and organizations were involved in this reporting system. The implementation of this preventive approach can be understood as an AML chain (Figure 1).

These reporting duties represent a significant investment on the part of the organizations concerned, requiring them to be able to distinguish between suspicious and non-suspicious transactions. Additionally, the participating organizations need to develop the requisite skills, instruments and competences to detect potential money launderers and those involved in terrorist activities. In the case of banks, this has led to the assignment of specific employees to the AML role: the compliance officers.

In Belgium and elsewhere, the AML complex is based on a risk-based approach (FATF, 2007). Rather than depending solely on rule-following or the application of objective indicators, the system offers scope for interpretation and discretion, focusing on the investigation of transactions and clients that represent a higher risk of money laundering. The approach is based on "intelligent reporting" (as opposed to automatic reporting, which is based on specific objective criteria). This implies that banks are granted room for discretion in reporting transactions to the FIU. Intelligent reporting also means that the bank functions as a first filter before cases are forwarded to the FIU, potentially resulting in more efficient functioning of the system.

Figure 1.

The AML Chain

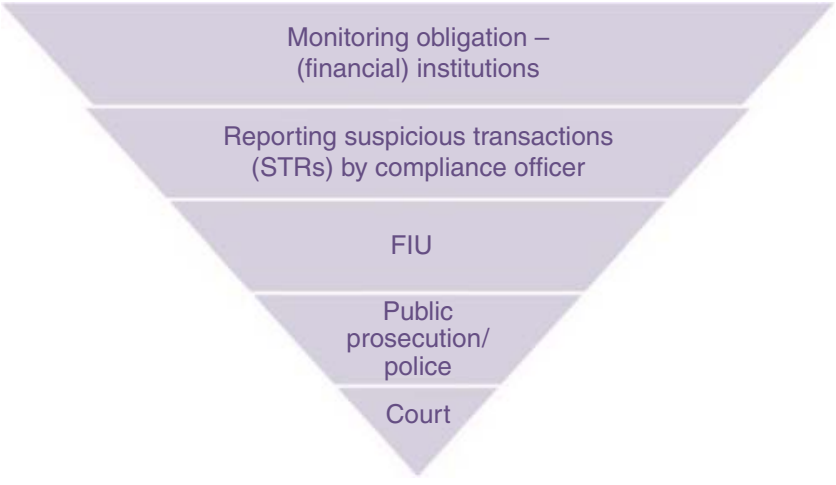


During the period 2006-2009, the compliance officer became the focal point of study. As a bank employee required to implement legislation that is not always in the bank's commercial interest, the difficulty of the compliance officer's role was seen to be an important issue.

The present study sought to gain some insight into the compliance function within financial institutions, based on the central hypothesis that the AML complex and the compliance industry are parallel constructions - both operating in the same domain but based on different objectives and motivations. These differences in motivation might be expected to result in differing attitudes and working methods, revealing the dilemmas faced by actors within AML (Figure 2).

The AML complex consists of the activities of private and public actors, carrying out regulatory, monitoring, reporting, investigative and judicial tasks; its objectives are prevention, crime fighting and law enforcement. The AML complex is based on legislation and regulation. Although it is a global rather than a regional system (Buzan et al., 1998), it can be seen as heterogeneous, comprising a multiplicity of actors who surround, support or actively engage in the battle against money laundering.

The compliance industry is an entrepreneurial market, providing services and tools in support of the fight against money laundering. This industry stimulates investment in compliance and AML by supplying monitoring systems, blacklists, training and advice to corporations that are obliged to implement AML legislation. The compliance industry provides a service that is additional to AML regulation, in which AML compliance is marketed as a product for sale.

Financial institutions play a central role in the space between these constructions, augmenting and interacting with both the complex and the industry. As the employee of a financial institution, the compliance officer highlights this paradox. As a go-between, they must strive continuously for a balance between the interests deriving from the two structures: a commercial orientation within an entrepreneurial environment as against crime-fighting and prevention. The complex and the industry were studied from exactly this viewpoint of a dual role.

\section{Methodology}

The present article draws on the results of two studies, from 2006-2009 and 2015.

\subsection{Study 1}

The first study employed a multi-methodological approach (Ponsaers and Pauwels, 2002; Bijleveld, 2005), combining quantitative and qualitative measures. The first phase of empirical data gathering used a web survey as quantitative instrument, followed by a qualitative phase that included semi-structured interviews, open source and literature research and observations. The web survey was accessed by compliance officers in Belgium through an

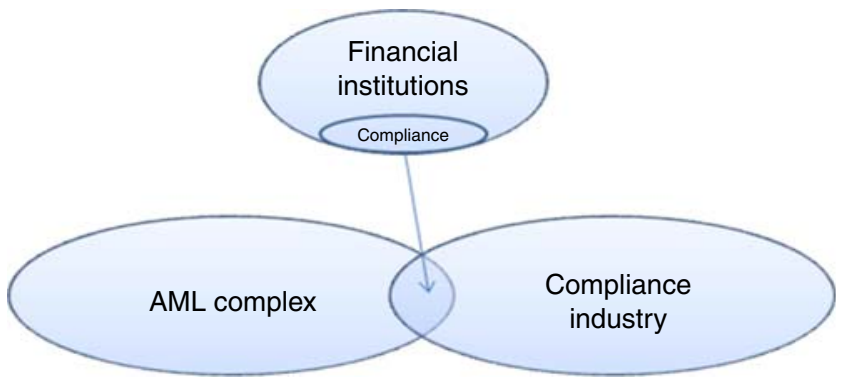

Figure 2. AML complexcompliance industry relations 
IJSSP

$37,7 / 8$

482

intermediary (the umbrella organization Febelfin) and attracted 74 respondents. The survey was carried out in accordance with the Dillman method (Dillman and Bowker, 2001) and provided the necessary basic information for subsequent phases. The 32 interviews that followed[8] enabled more in-depth dialogue with respondents and added more context to the earlier results[9]. Compliance officers are not easily found; contact was made by means of calls to general information telephone numbers and messages to general e-mail addresses. Use was also made of the snowball method; following an interview, respondents were asked who else they might recommend for interview. The interviews were recorded and then coded and analyzed using MAXQDA. As a field test, the analysis was subsequently sent to a number of respondents, with a follow-up visit to the banks at the end of the study to review the latest developments, as the credit crisis had occurred during the course of the study.

\subsection{Study 2}

In the Spring of 2015, a small-scale explorative study was undertaken to test and update the results of the first study (2006-2009). In total, 12 compliance officers were interviewed[10], using a topic list that included questions on the position of the compliance officer, the functioning of AML in the bank and how compliance officers assessed the evolution of their role. Compliance officers were randomly selected from both small and larger banks. The interviews were coded and analyzed by the author in Nvivo. This small-scale study largely confirmed the conclusions of six years previously.

Rather than discussing all the research results, the present paper will review the main general conclusions related to the fight against money laundering. Other publications (Verhage, 2011, 2012) discuss the results of the first study in greater detail.

\section{Functioning of the AML complex}

In general, compliance and AML provisions were found to have permeated Belgian banks. Occasionally, a compliance officer noted that battles had to be fought in balancing commercial interests and rule abidance. This is probably an inherent feature of the AML task and does not conflict with the general view that, without compliance, banks could no longer function.

\subsection{Lack of feedback}

One of the most remarkable and recurrent findings of this study was the lack of feedback within the AML chain. Information provision goes mainly in one direction: from banks to law enforcers. However, information provision is confined to what the banks want law enforcers to know and what the reporting duty obliges them to report. The mutual sharing of information is in practice quite limited, and there is little will to change this:

There are no definitions. What a 'shell company' is, is not defined. Or what is an offshore area, or a financial haven? There are absolutely no definitions. We have asked the FIU, as they have prepared these indicators, but they say: we have written the indicators on the basis of your reports. So [...] we are actually doing the job of the judicial police? ( $\mathrm{Cpl} \mathrm{15).}$

This lack of information sharing and transparency - in terms of providing feedback as well as non-reported atypical constructions - may not be entirely positive in its effect on the system's functioning. Additionally, the AML complex does not seem to develop the knowledge that it might in theory be expected to develop; in practice, knowledge accumulation seems very restricted:

In fact, we try to put together the information of the branch office, the information we have here, based on the overviews of accounts and information found on the Internet; we see if this adds up and, if necessary, we look for complementary information (Cpl 5). 
Cooperation between public and private actors in the chain cannot be described as smooth. Unlike their French colleagues, Belgian compliance officers cannot fall back on their former colleagues in law enforcement, which may partly explain the lack of cooperation (Favarel-Garrigues et al., 2008). A minority of respondents stated that they exchanged some information on an informal basis, but this was based mainly on personal contacts or years of cooperation.

Among banks, a high level of informal cooperation was noted. Compliance officers knew each other (a small world) and are now also allowed to exchange information on investigations. More formal possibilities for cooperation and information exchange were welcomed by respondents. It might allow for pooling of information by different banks (knowledge accumulation), enabling identification of suspect clients and clusters of clients and transactions at an earlier stage.

Compliance officers also pleaded for the development of a blacklist of clients, which could help to prevent "bank shopping," as clients looking for the least strict bank would quickly be discovered. Police respondents further stated that they lacked information about the monitoring systems and criteria used within banks. Tools used by banks might very well provide the police with useful information - relating for example to criteria, scenarios or volumes of transactions - but information exchange on this issue remains very limited. Police services are not informed about how these mechanisms are applied, whether checks are run manually or by use of software, and so on. On the other hand, compliance officers stated that they would be very interested to know which patterns are detected by police services as a means of enhancing their own monitoring systems:

We have to be able to prove that we have done our job. But how will a judge react in case of a problem? You may never know. Maybe, for a judge, simply the fact that the money comes from Luxembourg is sufficient to be suspicious. But that's for the judge to decide, and we will not know this for another few years, when something goes wrong ( $\mathrm{Cpl} \mathrm{15).}$

Of course, guarantees must necessarily be built into any such exchange of information, both in interbank communication and between public and private actors.

\subsection{Limited view}

One important finding related to the limited view of impact and effect within the AML chain. As explained earlier, measurement problems arose at every level of the AML chain, and better statistics are badly needed as a basis for evaluation (Verhage, 2014).

\subsection{Dilemmas}

It was also concluded that responsibility in the AML complex is concentrated at the base, with the reporting institutions. It remains in question how this system can effectively prevent and fight crime when this base is not provided with sufficient information. This lack of information forces banks either to depend on (outdated) stereotyping criteria or to develop their own criteria, with the result that banks determine the threshold for reporting and there is a tendency to utilize the services of the compliance industry. In making the compliance industry responsible for determining these criteria and for providing information such as blacklists, application by the authorities of quality standards to their services and instruments is undoubtedly encouraged, arguably leading to a false feeling of security:

The problem is that we have to build scenarios, and we get a lot of alerts, and we have to check all of them to see if these are legitimate alerts. And people who really want to launder money still can: they know that kind of software, they know how [...] We need to have this software [...] but really $[\ldots]$ it's ok to have it, but as for the time it consumes [...] (Cpl 13). 
IJSSP

$37,7 / 8$

484

I can say to our IT department: 'Make sure that the system gives us 20 alerts per day'. You can do that! You can set your parameters so high that nothing will come out. And at the end of the day we can say we have processed $100 \%$ of our rules. Good job! But what kind of risk are you taking? (Cpl 12a).

Finally, it was noted that the non-transparency of the norms and concepts surrounding "risk" that are used throughout the battle against money laundering can have an important impact on fundamental rights:

The only thing you can do is write a sound policy, communicate it and try to prevent as much as possible; monitor, but you can never be $100 \%$ certain that you will not be sanctioned for laundering money - that is impossible. You can only try to prevent it to the largest extent possible, make reports of high quality and prove to the court that we are actually doing our job. That's the risk of working in a compliance function ( $\mathrm{Cpl} 12 \mathrm{~b})$.

The study questioned the extent to which the costs of this system are proportionate to the benefits. As the AML system is currently characterized by a reactive approach, based on information from the past (Crawford, 2009) that is also limited in scope and sources (Gelemerova, 2009), the danger exists that this may be a static system that is predestined to identify the same "usual suspects" again and again.

\section{AML today: new developments, same challenges}

On studying the apparatus for the fight against money laundering, it becomes clear that a new form of policing has emerged. This is sometimes referred to as "new policing" (Levi, 1997), "banking detectives" (Kochan, 2006), "the transnationalisation of policing" (Sheptycki, 2000) or "policing the money." By implication, the compliance officer has become one of the new actors in the policing landscape, adding to the multilateralisation of policing (Favarel-Garrigues et al., 2008). The introduction of the term "AML complex" is therefore useful, as it highlights the multitude of actors active in this field, from different backgrounds and with diverse motives. It also illustrates the differences in power position of each actor involved in this battle.

In the small-scale study conducted in 2015, the above conclusions still stand. Although there is clearly a lot of movement in AML policy, as in the (future) implementation of the 4th European Directive, a number of initiatives by national legislators (e.g. the introduction in 2011 of a licensing system for compliance officers in Belgium), many of the same problems remain. The next section examines a number of these issues.

\subsection{The need for empirical data}

The domains of compliance and AML evolve quickly, making it essential for research to keep up with these developments. Furthermore, given the risk-based approach, more insight is needed into the practices of the system in order to understand how the actors in the AML system employ their discretion and how they fulfill their AML tasks.

Respondents pointed to the importance of the compliance function in preserving the reputation of the bank:

They want to launder more and more money because there is a lot of it that is still circulating. Is it useful (the compliance function, AV)? One the one hand, yes, but I think that for those people who have black money, it is a disaster [...] you cannot do anything with it, you cannot go somewhere with it [...] I will not burn my fingers for someone else, I will not do that. No matter how well I know them, I will not do that (Cplb 1).

It seems that the dilemmas that compliance officers previously faced are now less prevalent. Most respondents stated that they believe rule-abidance takes precedence over commercial goals - a clear sign that the compliance function has evolved further as a professional sector. Some also referred to the BNP-Paribas-case[11], noting an ensuing new awareness of 
the importance of a compliance department and the need to play by the rules. A majority of Policing money the respondents also stated that compliance budgets have increased in recent years, and the number of FTE working in compliance is on the rise in many of their departments. In short, laundering the sector has evolved very rapidly and is now taken seriously:

INT: So you are more careful?

CPL1: Certainly. Because it all comes down to us [...] It used to be no problem, no one paid attention to it, but now [...] you simply cannot do that. Because we are too much under [...] big brother is watching you. And that is not worth it! (Cplb 1).

Another visible change is that, in contrast to the earlier interviews, compliance officers now talk openly about information exchange between banks. Although not (always) officially allowed, this is no longer a taboo:

When an agent receives a new prospect, and is in doubt whether or not to accept him or her, and we know that he/she used to be a client at X, what will we do? More than probable will we contact our colleagues at X, the AML department, to ask "Wait, why is this client no longer with you? Do you have a file on him? (Cplb 3).

But, some things have not changed; the fact that compliance officers are often faced with difficult decisions in "gray areas," or when they are uncertain if something suspicious is going on, continued to be mentioned regularly in interviews. More support and more feedback remain important issues, especially as the pressure on compliance has grown as a result of the greater importance of compliance departments in relation to controls and checks.

\subsection{Uneven playing field}

As illustrated by the introduction of the 4th European Directive[12], implementation of AML in Europe remains an uneven playing field (Verhage, 2015) as a consequence of diverse interpretations and implementations of the European Directives by Member States[13]. This is well illustrated by differences in reporting requirements, levels of enforcement, predicate crimes and counting rules in registration of AML cases. The uneven playing field is a crucial impediment in the AML battle, presenting opportunities for anyone looking for loopholes or the path of least resistance. The regime is also built around the assumption that it will become a global system (Levi and Reuter, 2006).

The European Commission's (2013) Impact Assessment a study that preceded the current proposal for the 4th Directive, also refers to how financial institutions that are active at international level face several difficulties in implementing their AML policy at group level because of inconsistencies in AML legislation in different countries. Indeed, compliance officers acknowledged in the interviews that they are sometimes highly challenged in their AML tasks for this reason, with difficulties related to information exchange, approach, monitoring, analyzing and reporting. This is also why many banks have both a national and an international interpretation and policy for AML, aside from their global policy.

Awareness of the uneven playing field is not new; it has been discussed in the literature and was translated into attractiveness scores almost ten years ago (Unger, 2006). Although the 4th Directive seeks harmonization, a necessary first step is to map the diversity of systems, using sound and uniform registration methods at every level of the AML chain. This brings us to the second major issue: the current limitations of registrations and statistics.

\subsection{Limited statistics and diversity of sources}

The limited availability of statistics and sources related to money laundering remains problematic. The fact that results in a very fragmented picture, requiring researchers to 
IJSSP

$37,7 / 8$

486

resort to a diversity of sources. In general terms, it remains the case that, because this type of crime involves multiple actors, cross-border information remains fragmented, and researchers must still resort to gathering bits and pieces of information from diverse sources (which are neither complementary nor comparable). This makes it very challenging to map the chain of AML, and we urgently need sources that are sufficiently detailed to facilitate analysis, comparison and data matching. This is a crucial research objective that has gained in importance, given the priority now assigned to financial crime at policy level. In seeking to develop evidence-based policy, this is a crucial step. It is scarcely credible that, after 20 years of AML, it remains impossible to make an impact assessment of the progress being made.

7.3.1 Other problems in AML. In the Spring of 2015, the FATF published its mutual evaluation report on the Belgian approach to countering money laundering. The report made a number of positive observations but was also very critical in some respects. The evaluation indicated that a risk-based approach is not well elaborated: "its understanding of these risks is fragmented and incomplete" (FATF, 2015). The FATF concluded that an overall AML approach that includes prioritization and resource allocation is still lacking today and noted the lack of detailed statistics in this regard, which also implies a lack of case management strategies. The FATF also criticized the lack of resources at police level in dealing with such crimes. This lack of resources is not only detrimental to detection, prosecution and sanctioning but also results in a very high level of policy dismissals (FATF, 2015).

\section{Directions for further research}

Offering insights into how the phenomenon of money laundering is tackled, how policing involves different actors and the unrealistic expectations around the AML system arising from a lack of clear criteria, ineffective feedback systems, and so on, these findings have several implications for further research. First of all, research in this domain should focus on gathering insights on the phenomenon and characteristics of money laundering. In line with earlier research (Kabki, 2014), it would be useful and relevant to analyze files on money laundering in order to relate criminological theories of offending to money launderers in closed cases. This presents numerous theoretical challenges.

Second, further research is needed to quantify the phenomenon of money laundering in a way that facilitates a baseline study. This should enable at least a first step toward a system of assessment in AML; any system that is this intrusive should at least be able to show its effectiveness. We should also find out more about the displacement effects of AML barriers - for instance, do these lead to increased use of hawala banking systems? Do they imply the invention of parallel banking systems, or are banking systems circumvented completely? And how should police and public prosecutors deal with these developments? One example of such a study is the work of Dotti et al. (2015), in which indirect measurement methods (i.e. the spatial mapping of deposits of large denomination banknotes in banks) were used to measure local variations in the shadow economy. Such measurements can use both quantitative and qualitative methods, and the latter could also be used to explore whether money laundering indeed results in higher levels of power at the level of the formal economy. This was, after all, part of the rhetoric at the outset of the fight against money laundering.

In relation to AML policy, it is noteworthy that, despite their central role in AML, there is no mention of compliance officers in the 4th European Directive, and they are not involved in official regulation at EU level - even though some countries (including Belgium) have assigned legal status to compliance officers. However, there is movement on another level; ISO 19600 is in preparation (See www.iso.org/iso/catalogue_detail.htm?csnumber=62342), containing standards for compliance management that can be used as guidelines to regulations and legislations that an organization must deal with. It remains to be seen to what extent this will also apply to AML. 
Banks and compliance officers are (and will continue to be) the go-betweens in this Policing money system. In light of the BNP-Paribas-case and other similar cases, a lot of questions remain unanswered. Should we not think about ways to give the compliance officer more authority or power (and status within the bank)? How can we improve support for non-commercial decisions? How can we clarify their role as whistleblower? In conclusion, if we are to conduct an effective war against money laundering, we must strive for a level playing field and seek to avoid attraction pools for money launderers, as these impact both on competitive positions and on the overall effectiveness of AML.

\section{Notes}

1. Lernout and Hauspie, Enron (Huisman, 2009), the BCCI scandal, the HSBC scandal, [...].

2. This takes into account the review of 15 high-ranked journals, 13 handbooks and all US doctoral school programs between 2001 and 2010 related to white collar crime.

3. More information can be found in: Verhage (2014).

4. The latter includes only internal fraud; see WODC (2011).

5. See Eurostat (2013).

6. Directive 2005/60/EC of the European Parliament and of the Council of October 26, 2005 on the prevention of the use of the financial system for the purpose of money laundering and terrorist financing; Directive 2001/97/EC of the European Parliament and Council of December 4, 2001 amending Council Directive 91/308/EEC on prevention of the use of the financial system for the purpose of money laundering; and Directive 91/308/EEC of the Council of June 10, 1991 on prevention of the use of the financial system for the purpose of money laundering. The 4th Directive was adopted by the Commission in February 2013 and came into force in June 2015. Its implementation is expected in 2015/2016.

7. Directive (EU) 2015/849 of the European Parliament and of the Council of May 20, 2015 on the prevention of the use of the financial system for the purposes of money laundering or terrorist financing, amending Regulation (EU) No 648/2012 of the European Parliament and of the Council, and repealing Directive 2005/60/EC of the European Parliament and of the Council and Commission Directive 2006/70/EC.

8. In total, 32 interviews in total were conducted with 23 compliance officers, six police officers, three regulatory agents and six members of the compliance industry.

9. More information regarding the methodology can be found in Verhage (2009).

10. The interviews were conducted by students within the framework of an optional course (2014-2015). The participating students were Louise D'Eer, Sarah De Kinder, Elien Heyvaert, Kimberly Lossie, Jolien Touchant and Thea Vander Vennet. Many thanks to them for their enthusiasm and perseverance.

11. BNP Paribas made (recurring) transactions totaling $\$ 8,833,600,000$ to countries considered no-go areas by the USA, including Sudan, Iran and Cuba. Despite repeated red flags and frequent alarms raised by compliance departments of different countries (red flags had been raised since 2004, first in Geneva, later also in Paris), transactions to those countries passed because they were seen as "historical opportunities" and concerned transactions for a "privileged partner." This made commercial interests apparently more important than the risk they took. Additionally, the bank actively sought ways to disguise these transactions and to prevent disclosure of these countries' involvement. They instructed employees to remove countries' names from the transaction messages and instructed other organizations to do the same (US Justice Department, 2014). As such, huge amounts of dollars flowed to countries that the USA wanted no financial ties with because of their known support for international terrorism and human rights abuses. 


\section{References}

Bijleveld, C. (2005), Methoden en Technieken van Onderzoek in de Criminologie, Boom Juridische Uitgevers, Den Haag.

Bisschop, L. and Verhage, A. (2012), "The complex(ity) of policing dirty crime", in Ponsaers, P., Gunther Moor, L., Greene, J., Skinns, L., Bisschop, L., Devroe, E., Verhage, A. and Bacon, M. (Eds), Tides and Currents in Police Theories, Maklu, Antwerpen and Apeldoorn, pp. 273-290.

Blickle, G., Schlegel, A., Fassbender, P. and Klein, U. (2006), "Some personality correlates of business whitecollar crime", Applied Psychology, Vol. 55 No. 2, pp. 220-233, doi: 10.1111/j.1464-0597.2006.00226.x.

Braithwaite, J. (2000), "The new regulatory state and the transformation of criminology", British Journal of Criminology, Vol. 40 No. 2, pp. 222-238.

Buzan, B., Wæver, O. and De Wilde, J. (1998), Security: A New Framework for Analysis, Lynne Rienner Publishers, London.

Collins, J. and Schmidt, F. (1993), "Personality, integrity, and white collar crime: a construct validity study”, Personnel Psychology, Vol. 46 No. 2, pp. 295-311, doi: 10.1111/j.1744-6570.1993.tb00875.x.

Crawford, A. (2009), "Governing perceptions of crime and (in)security in an age of uncertainty", paper presented at the Final Crimprev Conference on Deviance, Crime and Prevention in a Punitive Age, ICCCR - Open University Milton Keynes, June.

Croall, H. (2001), Understanding White Collar Crime, Open University Press, Buckingham.

De Bie, B. and Verhage, A. (2010), "Fraudebestrijding in België anno 2010: quo vadis?", Orde van de dag: Criminaliteit en samenleving, No. 51, pp. 7-16.

Deloitte (2011), "Final study on the application of the anti-money laundering directive", EUROPEAN COMMISSION.

Dillman, D. and Bowker, D. (2001), "The web questionnaire challenge to survey methodologists", in Reips, U. and Bosnjak, M. (Eds), Dimensions of Internet Science, Pabst Science Publishers, Lengerich, pp. 53-71.

Dotti, N.F., Van Heur, B. and Williams, C.C. (2015), "Mapping the shadow economy: spatial variations in the use of high denomination bank notes in Brussels", European Spatial Research and Policy, Vol. 22 No. 1, pp. 5-21.

European Commission (2013), "Impact assessment accompanying the document proposal for a directive of the European Parliament and of the council on the prevention of the use of the financial system for the purpose of money laundering, including terrorist financing and proposal for a regulation of the european parliament and of the council on information accompanying transfers of funds", Commission Staff Working Document, Strasbourg, available at: http://eurlex.europa.eu/LexUriServ/LexUriServ.do?uri=SWD:2013:0021:FIN:EN:PDF (accessed August 23, 2017).

European Commission (2014), "Report from the commission to the council and the European Parliament", EU Anti-Corruption Report.

Eurostat (2013), "Money laundering in Europe", Eurostat Statistical Working Papers, European Commission, Eurostat, available at: http://ec.europa.eu/eurostat/web/products-statistical-workingpapers/-/KS-TC-13-007 (accessed August 23, 2017). 
FATF (2007), "Guidance on the Risk-based approch to combating money laundering and terrorist financing, high level principles and procedures".

FATF (2015), "Anti-money laundering and counter-terrorist financing measures - Belgium", Fourth Round Mutual Evaluation Report, FATF, Paris, available at: www.fatf-gafi.org/topics/ mutualevaluations/documents/mer-belgium-2015.html (accessed August 23, 2017).

Favarel-Garrigues, G., Godefroy, T. and Lascoumes, P. (2008), "Sentinels in the banking industry. Private actors and the fight against money laundering in France", British Journal of Criminology, Vol. 48 No. 1, pp. 1-19.

Frate, A. (2004), "The international crime business survey: findings from nine Central-Eastern European Cities", European Journal on Criminal Policy and Research, Vol. 10 Nos 2-3, pp. 137-161, doi: 10.1007/s10610-004-4122-4.

Geis, G. (1993), “The evolution of the study of corporate crime”, in Blankenship, M. (Ed.), Understanding Corporate Criminality, Garland, New York, NY, pp. 3-28.

Gelemerova, L. (2009), "On the frontline against money-laundering: the regulatory minefield", Crime, Law and Social Change, Vol. 52 No. 1, pp. 33-55.

Gottschalk, P. (2010), "Categories of financial crime", Journal of Financial Crime, Vol. 17 No. 4, pp. $441-458$.

Huisman, W. (2009), "Kredietcrisis en organisatiecriminaliteit: vier mogelijke relaties", Justitiële Verkenningen, Vol. 35 No. 6, pp. 26-42.

Kabki, A. (2014), Fraude ontrafeld. Een studie naar de werkwijzen en drijfveren van fraudeurs, Boom Lemma Uitgevers, Den Haag.

Kochan, N. (2006), The Washing Machine. Money, Crime and Terror in the Offshore System, Duckworth, London.

KPMG (2007), "Global Anti Money Laundering Survey 2007: How banks are facing up to the challenge".

Levi, M. (1997), "Evaluating the 'new policing': attacking the money trail of organized crime", The Australian and New Zealand Journal of Criminology, Vol. 30, pp. 1-25.

Levi, M. and Reuter, P. (2006), Money Laundering, University of Chicago, Chicago, IL.

Lynch, M.J., Mcgurrin, D. and Fenwick, M. (2004), "Disappearing act: the representation of corporate crime research in criminological literature", Journal of Criminal Justice, Vol. 32, pp. 389-398.

McGurrin, D., Jarrell, M., Jahn, A. and Cochrane, B. (2013), "White collar crime representation in the criminological literature revisited, 2001-2010", Western Criminology Review, Vol. 14 No. 2, pp. 3-19.

Moore, T. (2013), "The promise and perils of digital currencies", International Journal of Critical Infrastructure Protection, Vol. 6 No. 3, pp. 147-149.

Piquero, N. and Clipper, S. (2014), "White collar crime", in Bruinsma, G. and Weisburd, D. (Eds), Encyclopedia of Criminology and Criminal Justice, Springer, New York, NY, pp. 5531-5538.

Ponsaers, P. and Pauwels, L. (2002), "De methodestrijd in de criminologie", in Beyens, K., Goethals, J., Ponsaers, P. and Vervaeke, G. (Eds), Criminologie in Actie. Handboek criminologisch onderzoek, Politeia, Brussels, pp. 55-72.

Price Waterhouse Coopers (2005), "Compliance: finance's bridge to the enterprise.

Reuter, P. and Truman, E. (2005), Chasing Dirty Money: The Fight Against Money Laundering, Peterson Institute for International Economics, Washington, DC.

Sheptycki, J. (Ed.) (2000), Issues in Transnational Policing, Routledge, London.

Shoham, S.G., Knepper, P. and Kett, M. (2010), International Handbook of Criminology, CRC Press, Boca Raton, London and New York, NY.

Slapper, G. and Tombs, S. (1999), Corporate Crime, Longman, London.

Tavares, C., Thomas, G. and Roudaut, M. (2010), "Money laundering in Europe. Report of work carried out by Eurostat and DG Home Affairs", Eurostat Methodologies and Working Papers, Eurostat. 
Unger, B. (2006), "The amounts and the effects of money laundering", Report for the Ministry of Finance, Den Haag, available at: www.rijksoverheid.nl/documenten-en-publicaties/rapporten/2006/02/16/ onderzoeksrapport-the-amounts-and-the-effects-of-money-laundering.html (accessed July 4, 2014).

US Justice Department (2014), "United States district court, Southern district of New York", United States of America v. BNP Paribas, S.A., Defendant, Statement of Facts, New York, NY, June 30.

van Erp, J., Huisman, W. and Vande Walle, G. (Eds) (2015), Routledge Handbook of White Collar and Corporate Crime in Europe, Routledge, Oxford and New York, NY.

Verhage, A. (2008), "Compliance in de Belgische financiële sector. Of hoe zelfregulering en overheidsregulering in elkaar verstrengeld raken", in Vande Walle, G. and Van Calster, P. (Eds), De criminologische kant van het ondernemen, Boom Uitgevers, Den Haag, pp. 87-98.

Verhage, A. (2009), "Corporations as a blind spot in research: explanations for a criminological tunnel vision", in Cools, M., De Kimpe, S., De Ruyver, B., Easton, M., Pauwels, L., Ponsaers, P., Vande Walle, G., Vander Beken, T., Vander Laenen, F. and Vermeulen, G. (Eds), Governance of Security Research Papers Series I, Contemporary Issues in the Empirical Study of Crime, Maklu, Antwerp, pp. 80-108.

Verhage, A. (2010), "The holy grail of money laundering statistics: Input and outcome of the Belgian AML system”, in van Duyne, P., Antonopolous, G., Harvey, J., Maljevic, A., Vander Beken, T. and von Lampe, K. (Eds), Cross-Border Crime Inroads on Integrity in Europe, Wolf Legal Publishers, Nijmegen, pp. 143-168.

Verhage, A. (2011), The Anti Money Laundering Complex and the Compliance Industry, Routledge, London.

Verhage, A. (2012), "The social analysis of the anti-money laundering complex and the compliance industry", in Ponsaers, P. (Ed.), Social Analysis of Security, Boom, Groene Gras, Den Haag, pp. $57-82$.

Verhage, A. (2014), "Op zoek naar financieel-economische criminaliteit. (In search of financial-economic crime)", in Pauwels, L., De Keulenaer, S., Deltenre, S., Devroe, E., Forceville, J., Hardyns, W., Kerkab, R., Maes, E., Moons, D., Plessers, J., Pleysier, S., Ponsaers, P., Van Dael, E. and Verhage, A. (Eds), Criminografische ontwikkelingen II: van (victim)-survey tot penitentiaire statistiek, Panopticon Libri, Maklu, Antwerp, pp. 89-112.

Verhage, A. (2015), "Global governance = global compliance?”, in van Erp, J., Huisman, W. and Vande Walle, G. (Eds), The Routledge Handbook of White-collar and Corporate Crime in Europe, Routledge, pp. 1157-1191.

WODC (2011), Monitor Criminaliteit Bedrijfsleven 2010. Feiten en trends inzake aard en omvang van criminaliteit in het bedrijfsleven, WODC, Den Haag, available at: www.wodc.nl

\section{Further reading}

Geis, G. (1995), "A review, rebuttal, and reconciliation of Cressey and Braithwaite and Fisse on criminological theory and corporate crime", in Geis, G., Meier, R. and Salinger, L. (Eds), White Collar Crime. Classic and Contemporary Views, The Free Press, New York, NY, pp. 450-469.

Price Waterhouse Coopers (2011), "Cybercrime in the SPOTLIGHT”, Global Economic Crime Survey, Belgium.

Ruggiero, V. (2002), "La criminalité économique et financière en Europe", in Ruggiero, V. and Ponsaers, P. (Eds), La criminalité économique et financière en Europe, L'Harmattan, Paris, pp. 7-17.

\section{About the author}

Dr Antoinette Verhage is a Professor of Criminology at the Department of Criminology, Criminal Law and Social Law at Ghent University, Belgium. She is a member of IRCP. Dr Antoinette Verhage can be contacted at: Antoinette.verhage@ugent.be

For instructions on how to order reprints of this article, please visit our website:

www.emeraldgrouppublishing.com/licensing/reprints.htm

Or contact us for further details: permissions@emeraldinsight.com 